\title{
Fra presseetik til markedsmoral
}

\section{AF MICHAEL BRUUN ANDERSEN}

Denne artikel argumenterer for, at det danske presseetiske system trænger til et hovedeftersyn. En historisk gennemgang af systemets tilblivelse kan forklare dets i international sammenhæng helt specielle karakter. Denne består i, at brud på presseetikken bedømmes af et uafhængigt, men korporativt sammensat pressenævn på grundlag af regler udformet af mediebranchen selv. Hele ordningen, som i udgangspunktet var avisbranchens eget system for selvjustits, er nu en del af medieansvarsloven. Denne konstruktion gør gældende praksis vanskelig at gennemskue, og blokerer for en nødvendig diskussion af journalistikkens samfundsmæssige opgaver og grænser på det 21. århundredes stadigt mere kommercielle mediemarked.

\section{Indledning}

Interesserer man sig for presseetik varer det ikke længe, før det går op for én, at området i Danmark er præget af en række mærkværdigheder, som ikke er helt lette at forstå eller at forklare for andre, således som det er nødvendigt, hvis man underviser journalister i presseetik. Der findes ikke nogen systematisk presseetisk debat i Danmark, fx i brancheblade o.l. Det står også skidt til med forskningen i medieetik. Sammenligner man fx Danmark med Norge eller Sverige bliver forskellen tydelig: I de andre lande publiceres en lind strøm af bøger om emnet, mens der her i landet findes en enkelt bog. Videre bliver man hurtigt klar over, at det gældende presseetiske regelsæt har en mærkværdig status, og at man må arbejde med mange dokumenter, hvis man vil vide, 
hvad god presseskik er. Yderligere er der i de seneste år fremkommet en lang række dokumenter fra de enkelte medier, som supplerer og delvis modsiger de presseetiske regler. Det strømlinede præg den særlige danske ordning opviser, synes at rumme en række problemer og rejse en del spørgsmål, som ikke får megen opmærksomhed. Det er nogle af disse problemer som denne artikel ønsker at drøfte, ikke fra et juridisk, men snarere fra et historisk-sociologisk synspunkt.

\section{Kort tidslinje}

Det danske presseetiske system har ikke fået sin egen forskningsbaserede historie. Det følgende er ikke en sådan historie, men blot nogle hovedlinjer. Systemet har en kort historie sammenlignet med landene omkring os. Denne forsinkelse har formentlig at gøre med, at processen var præget af stærke interessemodsætninger på kryds og tværs i den danske medieverden. Man siger, at først med etableringen i 1991 af det, som nu ser ud til at være den endelige ordning, etableres de danske medier som et sammenhængende system, eller bedre: Det bliver synligt, at der er et system. Forløbet kan indledningsvis kort skitseres ved at afsætte en række mærker på tidslinjen. Disse mærker repræsenterer vigtige begivenheder og indspil til systemets etablering:

I 1960 får vi det første regelsæt. I 1964 skabes en slags sanktionssystem ved etableringen af et pressenævn. I 1968 udvides reglernes anvendelsesområde, og i 1972 udvides reglernes mediemæssige gyldighedsområde. I 1971 anbefaler Straffelovrådet i en betænkning et presseetisk system, som kan aflaste retssystemet. I 1981 kommer der nye regler, som går uden for retsreportagen, og et nyt nævn. Stadig er der tale om frivillige, selvpålagte reguleringer af ytringsfriheden, og reglerne gælder ikke for alle medier, og ikke alle pressens organisationer er med i systemet. I 1985 anbefaler mediekommissionen, at der etableres et fælles system for alle de danske medier, og i 1990 anbefaler medieansvarsbetænkningen, at presseetikken bliver en del af den danske lovgivning, og at den omfatter alle medier. Forslaget blev til lov i 1991. Systemet etableres altså i den 30-årige periode fra 1960 til 1990. 


\section{Den tidlige historie}

En række offentligt tilgængelige dokumenter, betænkninger m.v. fortæller alle i hovedtræk den samme historie, nemlig at de presseetiske regler var et anliggende for arbejdsgiver- og udgiversiden, som kæmpede for etableringen af sådanne regler trods interne uenigheder. Det er ikke helt forkert, idet arbejdstagersiden ikke kom med i systemet før helt til sidst. Men det er heller ikke helt rigtigt. Journalisterne fortæller en lidt anden historie. Den tidligere formand for Dansk Journalistforbund V. F. Michaelsen beskrev i 1976 forløbet som en kamp både mellem og internt i organisationerne, men han tilføjede:

„I den aktuelle situation kan det tage sig ud, som om det er journalisterne (...) som er den vrangvillige part. Men går man tilbage, så kan det i hvert fald statistisk opgøres, at det er journalisterne, der har repræsenteret den udfarende kraft, som de fleste gange har taget initiativet, og at det er redaktør-organisationerne der har afvist“.

(Michaelsen, 1976: 134)

Han går tilbage til 1937, når han skal finde begyndelsen. Det er samme årstal som arbejdsgiverne/udgiverne anfører, når de skal fortælle historien, men de nævnte anledninger er forskellige. For Danske Dagblades Forening (DDF) var det en juridisk udredning af Stephan Hurwitz på et nordisk juristmøde i 1937, som var anledningen (Betænkning angående ..., 1977: 9), mens det for Dansk Journalistforbund (DJ) var en tale af statsminister Stauning. Talen nævner i forblommede vendinger pressens misbrug af ytringsfriheden og hans skepsis mod en skærpelse af presseloven. Men måske kunne en „æresinstans“ være nyttig, citeres han for at have sagt. Journalisterne var lydhøre og kom med forslag til DDF, men blev afvist. Således også et fornyet initiativ i 1938. Med den tyske besættelse døde diskussionen.

I 1947 tog journalisterne igen initiativ over for DDF, og denne gang modtages det positivt, måske fordi der i Dansk Kriminalistforening samme år blev udarbejdet forslag til visse retningslinjer for retsstoffets behandling (Betænkning angående ..., 1977: 9). I 
perioden frem til 1954 arbejdes der med rammerne for et opinionsnævn, og journalisterne tilslutter sig tanken. Men den møder modstand i DDF, og bedre blev det ikke, da man skulle fortsætte med at udarbejde en „moral-kodex for pressen“. Igen døde sagen. I 1959 tog DJ atter initiativ, og denne gang skete der noget. Det første regelsæt, som koncentrerede sig om retsstoffet eller kriminalreportagen, blev udformet af DDF i samarbejde med jurister, her i blandt den tidligere nævnte Stephan Hurwitz.

På grund af uenighed i mellem redaktørforeningerne - ikke mindst om muligheden af et pressenævn som sanktionsinstans blev sagen imidlertid kørt på en sådan måde, at journalisterne blev spillet af banen. Reglerne blev vedtaget af arbejdsgiversiden i 1960. Derefter arbejdede man videre med et pressenævn, som blev vedtaget ensidigt af DDF. Journalisterne blev opfordret til at være med, men da Dansk Journalistforbund ønskede et egentligt opinionsnævn for pressen og paritet ved sammensætningen af nævnet, ville DDF ikke have journalisterne med. Dermed var DJ ude, og forblev ude indtil etableringen af den nugældende ordning i 1991.

Den seje og langvarige tilblivelsesproces var således tilsyneladende drevet af journalistsiden. Det var den, som skubbede på og tog initiativet. Da arbejdsgiverne endeligt var parate, var de internt uenige, hvilket medførte at journalisterne blev udmanøvreret. Det ser således ud til, at der var modsætninger internt på arbejds- og udgiversiden mellem de forskellige foreninger, men også mellem forskellige medier. Nogle aviser, fx Ekstra Bladet, var helt imod af principielle grunde. Samtidigt var der modsætninger mellem arbejdsgivere og arbejdstagere. Kampen stod om regler eller ikke regler, om hvor omfattende reglerne skulle være (hvilke stofområder, hvilke medier), om hvorvidt der skulle være et pressenævn eller ikke, om hvordan et sådan organ skulle sammensættes, hvis der skulle være et, og endeligt om spørgsmålet hvorvidt et presseetisk system skulle være et system for selvjustits i branchen eller om det skulle inkorporeres i det juridiske regelværk. En yderligere komplikation var Danmarks Radio, som siden 1964 havde sine egne publiceringsregler.

Hvorfor skulle det tage så lang tid? En af de forklaringer, som kunne komme på tale, men som ikke er nævnt med et ord i de her 
anvendte kilder, er det faktum, at Danmark under besættelsen faktisk havde et meget effektivt system for selvcensur: Reglerne fastsattes af Udenrigsministeriets Pressebureau, og sanktionerne (advarsler og bøder) blev „fastsat af et pressenævn, der var valgt af de danske redaktørorganisationer“ (Trommer, 1999: 75). Trommer bemærker, at pressen både før og efter den tyske besættelse var under „en vis statslig kontrol“, og anfører russernes besættelse af Bornholm, som det område, som efter besættelsen foranledigede 'selvjustitsen'. Set i dette historiske lys er det lettere at forstå både modstanden mange steder i den danske presse, og systemets endelige udformning: Der er tradition for statsorganiseret selvcensur.

Men hvad med argumenterne? Modstanderne var grundlæggende af den opfattelse, at de indskrænkninger, der allerede var af ytringsfriheden, var tilstrækkelige, og hvis de ikke var, måtte man jo lave lovene om. En presseetisk kodex vil blot begrænse ytringsmulighederne og pressens mulighed for at kontrollere og kritisere. Tilhængerne både på arbejdsgiver- og arbejdstagerside argumenterede først og fremmest med troværdigheden: „Det er ikke meget galt at konstatere, at der består en tillidskrise mellem pressen og befolkningen. Den er pressen selv skyld i“ (Michaelsen, 1976: 132). I DDF’s betænkning fra 1977 nævnes gentagne gange den offentlige kritik særligt af pressens behandling af straffesager. „Denne kritik deltes også af mange pressefolk, der tillige frygtede, at den offentlige debat kunne give anledning til lovgivningsindgreb, som ville skærpe vilkårene for pressens ytringsfrihed“ (Betænkning angående ..., 1977: 9). Det nævnes, at der i 1955 blev nedsat en privat komité med Københavns Universitetets rektor som formand med henblik på at komme den sensationsprægede journalistik til livs.

Pressekritikken, eller den journalistik, som kritikken rettedes imod, undergravede altså pressens troværdighed, og som en konsekvens heraf cirkulerede der forestillinger og forslag om gennem lovgivningen at begrænse pressens ytringsmuligheder. Selvjustits blev svaret, eller på mere moderne dansk: For at undgå 'censur' måtte man hellere indføre selvcensur for at opretholde sin legitimitet overfor både politikere og læsere. Denne strategiske tankegang går igen på både arbejdsgiver- og arbejdstager- 
siden i den årelange konflikt. Men hvad var dette med den sensationsprægede journalistik? Svaret må være, at det presseetiske systems etablering i Danmark falder sammen med tabloidpressens vækst: BT først og siden Ekstra Bladet. Men der er sandsynligvis tillige en anden faktor på spil, selv om dette først ses tydeligt i den senere del af systemets etableringsfase. Den sene danske ordning kan næppe ses uafhængigt af afviklingen af partipressen.

\section{Første regelsæt}

De første presseetiske regler fra 1960 handler om retsstoffet. Af indledningen fremgår, at de er sat i verden for at støtte offentlighed i retsplejen, for at bidrage til en „sund retsbevidsthed“ og for „at modvirke lovovertrædelser, og at udbrede kendskabet til disse på en sådan måde, at det virker i det præventives interesse“ (Bet. Angående ..., 1977: 37). Man bemærker, at det ikke er pressens kritiske rolle i samfundet som beskrives, men dens samfundsmæssige loyalitet, særligt på retsområdet, som er i fokus - en rolle, som vanskeligt kan løsrives fra pressens tætte sammenknytning med det politiske system. Man kan også formulere dette på en anden måde: Pressen vedkender sig i reglerne sit almene, samfundsmæssige ansvar. Læserne er dog ikke helt glemt: „Kriminalreportagens mål er i læseværdig form ...“ (\$ 1). Det bemærkes videre, at reglerne beskrives som „regler for god presseskik“, altså den formulering, som også indgår i Medieansvarsloven. Ligeledes omtales reglerne som vejledende på samme måde som de regler, som er knyttet til Medieansvarslovens bestemmelser om grundlaget for Pressenævnets funktionsmåde.

Tonen i regelsættet er myndigt normativt med stribevis af bydemåder og bør-udsagn: „Vis hensyn“ ( $(3)$, som leder tankerne hen på den norske såkaldte plakat: Voer varsom, eller „Billedstof kræver takt“ (\$ 4). At kalde nogen skyldig, før han er dømt, er ,forkasteligt“ ( $(2)$. Det er uklart, hvem der tales til. Formuleringer vedrørende navns nævnelse, som „Der skal i videst mulige omfang følges en fast og saglig linie ..." peger på at man ikke har villet specificere, hvem der tales til. Hvis man overhovedet kan finde et tiltalt subjekt, er det „pressen“, altså et kollektivt subjekt. Jour- 
nalisterne er som støvsuget ud af teksten, hvilket måske ikke er så mærkeligt, når man tænker på tilblivelseskonflikterne, og det forhold, at reglerne blev vedtaget på Danske Dagblades Fællesrepresentations møde (23. november 1960). Reglerne gælder formelt de medier, som har tilsluttet sig, og det kan næppe betyde andet end, at det er regler for redaktørerne, som så må fortælle de ansatte, hvad der gælder.

Reglernes indhold er imidlertid i hovedsagen en kodificering af, hvad der var gængs praksis vedrørende navns nævnelse, privatlivets fred, omgangen med kilder, forståelse af juridisk terminologi (anmeldt, sigtet, tiltalt, skyldig, dømt), forholdet mellem overskrifter og brødtekst, omtalen af selvmord m.m. Interessante er formuleringerne om den måde, (rets-)journalistikken skal bedrives: Der tales om „uhildede referater“, og at referatet fra „retsforhandlinger skal være objektivt og loyalt“. Hvad vi ser her, er tidlige formuleringer af den presseideologi, som skulle blive den 'partiafviklede' omnibuspresses, nemlig objektiv nyhedsformidling. Selv om det var retsreportagen, som der i særlig grad var tænkt på, kunne regelsættets gyldighedsområde senere udvides til også at gælde andre stofområder. Pressehistorisk er det interessant at notere sig, at retsreportagen bliver retningsgivende for andre dele af journalistikken.

\section{Andet regelsæt}

Det andet regelsæt blev formuleret under medvirken af DJ i 1977, og er i hovedsagen identisk med det 3., nugældende, vejledende regler for god presseskik. Men 1977-forslaget vandt ikke gehør på arbejdsgiver- og udgiversiden, og reglerne blev vedtaget af DDF i 1981, men ikke af DJ. Årsagen til at DJ ikke kunne være med var, at DDF ikke kunne acceptere det fælles forslag, særligt på grund af to elementer i reglerne, som var kardinalpunkter for DJ. Det drejer sig om den såkaldte non-informationsklausul, og om journalisters integritet, altså det at kunne sige nej til en opgave pålagt af arbejdsgiveren/redaktøren.

Lad os imidlertid kigge lidt på begrundelserne for overhovedet at ændre reglerne. Det fælles brancheudvalg siger, at der er behov for regler, som er fælles for alle medierne, altså en yderligere ud- 
videlse af reglernes mediemæssige gyldighedsområde. Videre begrundelser er mediernes samfundsmæssige ansvar, og behovet for at styrke offentlighedens tillid til medierne. Reglerne er, som tidligere tænkt præventive, i forhold til eventuelle „utilbørlige indgreb i pressens ytringsfrihed“.

Videre spiller i argumentationen stærkt ind de anbefalinger, som Straffelovrådet i en betænkning fremkom med i 1971. Der er grund til at opholde sig lidt ved synspunkterne heri. Synspunktet er, at forholdet mellem moral og ret må ses som et substitutionseller bedre: aflastningsforhold. „(...) en udbygning af det presseetiske system ville indskrænke behovet for anvendelsen af de almindelige retsregler i forhold til pressen“ (citeret efter Bet. 1205, 1990: 297). Hvis en sådan aflastning skal fungere, skal reglerne efter rådets opfattelse gælde også uden for retsreportagens område, omfatte alle medierne, et pressenævn skal også have tilslutning fra journalisterne, og nævnets sanktionsmuligheder skal skærpes til ikke blot at være udtale af misbilligelse.

Disse overvejelser gjorde tydeligvis indtryk i arbejdsgruppen. På ét punkt ville man dog ikke følge med. Man ville ikke have et pressenævn med beføjelser til at give bøder eller lignende. I revisionsudvalget drøftede man også for første gang, om reglerne skulle lovfæstes. Konklusionen er bemærkelsesværdig set i lyset af de nu gældende regler: Etiske retningslinier er ikke „egnet til regulering gennem lovgivningen“ (Betænkning Angående ..., 1977: 17).

Men der er flere bemærkelsesværdige synspunkter: I spørgsmålet om, hvem der i bedste fald skal være omfattet af reglerne, bliver det sagt, at det er af „afgørende betydning for pressens selvjustits og anseelse“, at regler omfatter alle medier "som henvender sig til almenheden“. Det vil sige, at publikationer, som ikke henvender sig til almenheden, ikke skal være omfattet, fx foreningsblade. Grunden, der angives, for at det er afgørende, at alle er med, er, at de der holder sig uden for i givet fald, ville få en konkurrencefordel: Det kan ikke „udelukkes, at blade, der ikke har tiltrådt reglerne, f.eks. af konkurrencemæssige grunde vil anvende en journalistik, der ikke lever op til den faglige standard, som de etiske regler er udtryk for" (s. 19). I praksis betyder dette, at de etiske regler kommer til at medvirke til en homogenisering 
af medieindholdet. Der er ikke plads i denne sammenhæng til at gå ind i de parallelle faktorer, som virker i samme retning i dansk presse, som fx etableringen af et uddannelsesmonopol i form af Danmarks Journalisthøjskole.

Revisionsudvalgets forslag er inspireret af de svenske regler, og da disse indeholder ret detaljerede regler vedrørende tekstreklame, får dette problem nogle ord med på vejen. Der foreslås en meget generel bestemmelse („Der bør opretholdes en klar skillelinie mellem annoncering og redaktionel tekst“), og det siges, at mere „detaillerede regler for dette område bør tages op i et udvalg, sammensat af repræsentanter for redaktører og journalister“. Et sådant udvalg er, så vidt det ses, aldrig blevet nedsat. Tværtimod kunne man sige: DDF havde i en årrække efter krigen et eget udvalg, der overvågede dette område. Så vidt man kan se ophørte udvalget med at fungere, nogenlunde samtidigt med etableringen af de presseetiske regler.

Den såkaldte non-informationsregel og reglen om journalistisk integritet voldte problemer. Dette var journalisternes (DJs) adgangsbillet til et fælles presseetisk system. Derfor var det afgørende for udvalget, at denne bestemmelse kom med, samtidig med at den ikke anfægtede den redaktionelle frihed. Derfor blev bestemmelsen indskrænket til at gælde „faktiske oplysninger af væsentlig betydning for offentligheden“, og der skulle tages hensyn til mediets særlige karakter og geografiske placering. Der var enighed om, at sager af denne type skulle kunne afgøres af det etiske nævn. Anderledes med den anden for DJ så væsentlige bestemmelse: Samvittighedsklausulen. Denne nægtelsesret er med i forslaget, men udvalget mener ikke, at reglen er egnet som grundlag for afgørelse af nævnet. Man ser her, at den særegne etiske forbrødring mellem arbejdsgivere og arbejdstagere har sine grænser. Man vil af forståelige grunde ikke have retten til at lede og fordele arbejdet beskåret.

Det fremgår ingen steder, hvilke grunde journalisterne har til at insistere på disse regler. I fraværet af arkivstudier er der åbnet for fortolkning. Utvivlsomt var non-informationsbestemmelsen inspireret af internationale diskussioner, bl.a. i UNESCO. Disse for DJ så væsentlige punkter kan under alle omstændigheder forstås som et - noget sent - forsøg på, at sætte bolværk op mod par- 
tipressens kontrol med journalistikken. Formuleret i mere generelle vendinger kan man tolke disse bestemmelser som journalisternes forsøg på at skaffe sig (relativ) autonomi over for det politiske system, som pressen havde været en del af. Det giver i denne forbindelse mening at sondre mellem journalistens politiske integritet og den kommercielle (Raaum, 1976). Dansk Journalistforbunds projekt var således at sikre medlemmernes politiske integritet. Den kommercielle skal vi komme tilbage til.

\section{Tredje regelsæt}

Medieansvarsbetænkningens anbefalinger fra 1990 viser en høj grad af kontinuitet i tankegangen, men på i hvert fald ét område er der tale om et radikalt skift. Det som i 1977/1981 ikke var egnet til lovregulering bliver 10 år senere en del af loven. Man leder og leder i betænkningen efter substantielle argumenter for, at etikken skal være et anliggende for 'staten', men finder ikke noget. Det siges, at det eksisterende presseetiske system ikke har været „fuldt tilfredsstillende“, og at årsagen hertil først og fremmest har med den omstændighed at gøre, at DJ „ikke har kunnet tilslutte sig ordningen“ (Medieansvar, 1990: 324). I et citat hedder det efterfølgende:

„Den frihed, der gennem de særlige ansvarsregler og kildebeskyttelsesreglerne er givet pressen, skal forvaltes således, at individets retsbeskyttelse tilgodeses bedst muligt“(s. 325). Det er her, mediernes samfundsansvar som nu i skarpere og mere præcis form end tidligere danner grundlaget for selvjustitsen. Hvis ikke selvjustitsen er effektiv, kommer lovgiverne og indskrænker friheden. Derfor må vi have én presseetik for alle, synes argumentationsrækken at være. Men det ser unægteligt mærkeligt ud, at man af frygt for lovindgreb mod pressen tilslutter sig en lov for selvcensur! Måden, man kommer ud af modsætningen på, er ved at sørge for, at de presseetiske regler ikke bliver en del af selve loven, men blot vejledende regler for et pressenævn, som beskrives som uafhængigt. Lovbestemmelsen om presseetik bliver en såkaldt generalklausul, der som bekendt siger, at „massemediernes indhold og handlemåde skal være i overensstemmelse med god presseskik“ (lovens $§ 34$ ). Hvad der så er god presseskik be- 
stemmes af Pressenævnet, som i sine konkrete afgørelser skal læne sig op ad de vejledende regler, og i øvrigt forholde sig til hvad der er skik og brug.

Når man således skal vurdere baggrunden for, at presseetikken efter 1990 ikke længere er et brancheinternt system for selvjustits, men et lovfæstet statsligt nævn på linje med mange andre nævn, så har man ikke meget at støtte sin fortolkning på. Det må imidlertid være rimeligt at påstå, at det som får de mangeårige modsætninger i mediebranchen til at gå op i en højere enhed af statslig karakter netop er, at kun en sådan konstruktion i praksis kunne vinde tilslutning fra alle sider. Journalisterne fik deres ønsker om non-information og integritet med i regelsættet og paritetisk repræsentation i nævnet, og DDF fik både journalisterne og alle de genstridige medier med i et fælles system. Man kan også sige, at det forslag, som blev fremlagt allerede i 1977, først kunne implementeres, da det blev en del af Medieansvarsloven. Selv forslaget om, at offentligheden skulle have en repræsentant i nævnet, blev gennemført. Også organisatorisk var der tale om et columbusæg: Statsliggørelsen gjorde det muligt, at fusionere hele tre tidligere nævn: Det gamle pressenævn, Berigtigelsesnævnet og Radionævnet.

De nye regler, som skal vejlede Pressenævnet, er i realiteten konciperet i 1977. Regelsættet er mere omfattende, klarere og mere logisk opbygget end de første regler. Reglerne dækker nu både den journalistiske proces og dens resultat, og den dækker også annoncerne, i det omfang andre bestemmelser ikke gør det. Hovedlinjen i reglerne er - i overensstemmelse med tidligere diskussioner og Straffelovrådets intentioner - en ikke-retslig 'ekstrabeskyttelse' af privatlivets fred. De er skrevet i et autoritativt sprog, men uden specificeret modtager. Man kan sige, at reglerne dermed taler til dem, som i henhold til loven har ansvaret for det der bliver sagt: Journalister/forfattere, redaktører og udgivere. Man noterer sig, at synet på pressen som samfundsbevarende institution er forsvundet. 


\section{Kritik af den danske konstruktion}

I de fleste andre demokratiske lande er presseetik et spørgsmål om brancheintern selvjustits. Og selvjustits er ikke nødvendigvis en dårlig ting (Raaum, 2003). Sådan er det også i Danmark. Det særlige ved den danske ordning er, at systemet er en del af lovgivningen, og som sådan kan ændres af lovgiverne. To modstående vurderinger kan gøres af dette. På den ene side har al lovmæssig begrænsning af ytringsfriheden som intention, at få borgerne til at tænke sig om, inden de taler, altså selvcensur. Presseetikken er set på denne måde ikke principielt anderledes end andre begrænsninger. Imidlertid er det ikke folk selv, som styrer hvornår grænserne er overtrådt ved andre ytringsfrihedsbegrænsninger. Mediebranchen styrer selv på presseetikkens område, og sanktionerne er moralske fordømmelser. På den anden side kan man have det synspunkt, som mange pressefolk har haft gennem tiden, og en del stadigvæk har, nemlig at hvis der skal ske begrænsninger i ytringsfriheden, så skal det være gennem almindelige love, og overtrædelser skal pådømmes af domstolene. Statsorganiseret selvcensur er en uskik.

Ser man den særlige danske ordning i lyset af den konfliktfyldte tilblivelseshistorie, er det ikke forkert at sige, at ordningen er en succeshistorie. Ordningen kører som smurt, og al ballade i branchen er lagt død. Pressenævnets kendelser kører med dødsenskedelig og uforståelig juridisk sprogbrug, som rulletekster over fjernsynsskærmen. Man zapper væk, og det var det. Man ser en kendelse i avisen og bladrer videre. En yderst sjælden gang er der en fræk avis, som tager til genmæle mod en kendelse i en leder hvormed fortælles, at et eller andet sted under overfladen er ikke alt idyl. Set i dette lys kan det se ud som om den danske presseetiske orden har kørt sig selv ud på et sidespor. Ingen bryder sig om det, ingen forstår rigtig, hvad der foregår. Troen på systemets effektivitet er dalende. Ubeføjede påstande?

Lad os starte med forståeligheden. Hvis man for eksempel skal forklare vordende journalister, hvilke regler man som journalist bør holde sig efterrettelig, kan man henvise til de vejledende regler fra 1977. En hurtig gennemlæsning vil for en journalistspire hurtigt afsløre, at der er mange problemer, som der slet ikke er 
taget højde for i disse 25 år gamle regler. Men hvad er aktuelt gældende? Her må man gå tilbage til den juridiske konstruktion i det danske medieetiske system: Vi har en regel ( $(34)$, den tolkes ud fra en vejledning (de presseetiske regler) og skik og brug, og tolkningen relateres til konkrete sager. Man har som på andre juridiske områder en regel og en 'retspraksis'. Hvis man vil se, hvad 'retstilstanden' er, må man følge med i ‘dommene' fra Pressenævnet. Dette forsøger man at gøre lidt lettere for den interesserede ved at lave en årsberetning, hvor kasuistikken gennemgås, og mere generelle betragtninger tilføjes. Meget nyttigt.

Hvis man vil have fuld tjek på området, må man altså kende beretningerne fra nævnet $i$ alle år. Dette gør 'retstilstanden' vanskelig at overskue. Medierne udvikler sig hele tiden, og jo længere tid der går, desto større afstand bliver der mellem 'retspraksis’ og de vejledende regler. På denne måde bliver de vejledende regler mere og mere til indvortes brug for nævnet, og mindre og mindre til udvortes brug for dem, som ikke bør overtræde dem. Der er helt åbenlyst behov for at få ajourført det vejledende regelsæt. Hvordan det skal ske er - måske særligt for en ikke-juridisk betragtning - ikke let at se. Reglernes uklare status i loven synes, at konservere status quo ante, og forhindre en vigtig og nyttig løbende debat om mediernes opførsel. Man kan bare ane, hvilken livlig debat blandt fagfolk og lægfolk en revision ville indebære. Man kan her henvise til den seneste (ikke særligt omfattende) revision af Vær Varsom plakaten i Norge, som gav anledning til en livlig debat.

Den hede og væsentlige debat om Muhammed-karikaturerne viste et andet problem i det presseetiske system i Danmark, nemlig at reglerne også er mangelfulde. Man kan med god grund mene, at det er problematisk, at man ikke kan finde vejledning i de vejledede regler om spørgsmål, som fx den gode tone. Reglerne er så at sige tænkt i en periode samtidig med børnerim à la „En neger gik på Vesterbro“, men skal virke i en helt ny samfundssituation, hvor Vesterbro er fyldt med - ja, hvad er det nu, vi skal kalde dem. Her er Pressenævnet dårligt vejledt. Internetjournalistik, blogging og andre teknologisk drevne forandringer af journalistikken er andre områder, hvor Pressenævnet er dårlig vejledt af reglerne. 
Men reglerne er ikke alene mangelfulde, de er også utilstrækkelige, ja måske burde man sige, at systemet ikke er gearet til at tage højde for en række centrale samfundsmæssige problemer, som pressen ikke selv kan eller vil løse. I de vejledende regler kan man læse, at „der bør opretholdes en klar skillelinje mellem annoncering og redaktionel tekst“. Det er en regel som ikke mindst skal tage sig af den såkaldte tekstreklame. Uanset at området også falder under markedsføringsloven og forbrugerombudmanden, kan man konstatere, at tekstreklame findes overalt i pressen, ikke mindst i mange af de tillæg, som har som formål at tiltrække annoncer på et bestemt område. I USA har man flere steder taget konsekvensen af denne uacceptable tilstand, og ladet annonceafdelingerne redigere tillæggene. Dermed sættes mediets redaktionelle uafhængighed og troværdighed ikke på spil.

Dermed er vi også tilbage ved integritetsproblematikken. Mens reglernes synes at kunne håndtere den journalisternes politiske integritet, så rejser spørgsmålet sig, hvordan det står til med journalisternes kommercielle integritet. Man kan her skelne mellem to former, nemlig den som knytter sig til tekstreklamen, og den journalistik som forveksler salgbarhed og seertal med journalistisk kvalitet (Raaum, 1976: 55). Hertil kan lægges den seneste markedsmæssige påvirkning af journalistikken, nemlig tilpasningen til bestemte segmenter. Projekter som Tattere på Loeserne (TPL) på Berlingske Tidende og Begavet Tabloid på BT fordrer ikke alene en journalistisk tilpasning til annoncelæsende og købedygtige delmængder af offentligheden, men implementeres tillige på en måde, så stofområder og journalistiske vinkler redigeres væk med begrundelser som: „Det du er i gang med der, det er ikke noget vore læsere er interesseret i“!

Her er de presseetiske reglers bestemmelse om journalistisk integritet ikke meget værd - rent bortset fra at dette heller ikke i udgangspunktet var tænkt som noget, Pressenævnet skulle tage sig af - men heller ikke non-informationsbestemmelsen synes at kunne forhindre denne udvikling. Journalister i det 21. århundredes medier kan ikke hente megen støtte til eller vejledning til kommerciel integritet i de gamle presseetiske regler. Den professionaliseringnorm, som understøttedes af uddannelsesmonopol, presseetiske regler og ideologien om objektiv journalistik, 
underløbes stille og roligt at markedskræfterne: Segmentering og nye løse ansættelsesformer. DJ burde være interesseret i at bidrage til en diskussion af nye regler, som kan understøtte journalistisk integritet i den nye situation, hvor pressen har gjort sig uafhængig af det politiske system, men nu trues af en anden, nemlig en afhængighed af markedet. Presseetik handler ikke mindst om at manøvrere på den nødvendige, men tynde forbindelseslinje mellem business og samfundsmæssigt ansvar, mellem børs og katedral. Dansk Journalistforbund har aldrig bygget katedraler og satset på en faglig etik for sine medlemmer. Man har satset på børsen og skaffet gode lønninger (Nissen Kruuse, 1991: 22f).

Som redegørelsen for de presseetiske reglers tilblivelse har vist, har mediebranchen klare strategiske interesser i sagen. Troværdighed hedder det igen og igen. Presseetikkens historie viser, at denne strategiske interesse genereres af forandringer på mediemarkedet, som truer mediernes troværdighed (Christians, 2000; Starck 2001). Meget tyder på, at også det danske mediemarked er inde i en fase med stor turbulens, som kan true troværdigheden. De jævnlige empiriske målinger af mediers og journalisters troværdighed viser, så vidt man kan se, stabilt, at journalisters troværdighed er lavere end mediernes, og at medierne ikke har samme troværdighed som tidligere. Ændringer i billedet kan ses på andre indikatorer. Gennem det seneste tiår har de enkelte medier ikke kunnet nøjes med den presseetiske troværdighedsgenerator. Nye tiltag er sat i værk for at booste troværdigheden. Mange medier har skaffet sig egne presseetiske regler som en del af en generel virksomhedspolicy (Elliot, 1997; Odén, 2001). Disse regler kan nu ses af alle og enhver på mediernes hjemmesider. Som yderligere tiltag i denne retning må ses udbredelsen af virksomhedsinterne presseombudsmænd, som nu langsomt breder sig fra den spæde start på Aktuelt til Politiken og DR (Bredal, 2001). I samme retning peger de mange mediekritiske klummer, som ikke mindst dagbladene indeholder. Her kommenteres ofte, men usystematisk presseetiske problemer.

Det er denne artikels påstand, at der danner sig et billede af en presseetisk situation i Danmark, hvor det eksisterende presseetiske system fungerer så effektivt, at ingen rigtig tager det alvorligt længere, hvor de presseetiske regler er ganske uigennem- 
skuelige, hvor systemet ikke længere kan tilgodese mediernes legitimationsbehov, og hvor reglerne ikke længere kan bruges som grundlag for journalisternes integritet vis-a-vis de kommercielle kræfters indvirken på medierne som virksomheder. Presseetik har ikke kun af branchestrategisk interesse. Presseetik kan også ses som en reminder om de pligter der følger af at have fået særlige rettigheder på ytringsfrihedens område. Presseetikken er sådan set et udtryk for mediernes samfundsmæssige ansvar og opgaver. Men hvem kan fastholde denne langsigtede samfundsinteresse når de kortsigtede privatinteresser melder pas, og når staten ikke har en solid pressestøtte som trumf? Der er i denne situation behov for en systematisk drøftelse af opdaterede vejledende regler, om der er behov for sådanne, og om det er muligt og ønskeligt at opretholde et fælles system for alle medier eller omvendt, om man skal have et fælles europæisk system, og om det skal være statsligt. Under alle omstændigheder er der behov for en presseetik for det 21. århundredes medier.

\section{REFEREN CER}

Betcenkning angående og udkast til regler for god presseskik og for Pressenæevnets virksomhed. (1977), København: Danske Dagblades Forening. Bjørn Bredal (2001): Loesernes redaktør. København: Politiken.

Clifford Christians (2000): "An Intellectual History of Media Ethics", pp. 15-46 i Bart Pattyn (ed.): Media Ethics: Opening Social Dialogue. Leuven: Peters.

Maria Elliot (1997): Förtroendet för medierne. Göteborg: JMG.

Knud Aage Frøbert (2000): Massemediernes frihed og ansvar. København: Greens.

Helle Nissen Kruuse (1991): Etik i Journalistik. Århus, Ajour.

Medieansvar. Betænkning nr. 1205 (1990), København: Statens Informationstjeneste.

Vagn Fleischer Michaelsen (1976): „Presseetikkens skæbne i organisationerne“, pp. 131-141 i Pressens Årbog 1976, København: Hans Reitzel.

Tomas Andersson Odén (2001): Redaktionell policy. Om journalistikens mål och inriktning $i$ svensk dagspress. Göteborg, JMG. 
Odd Raaum (1976): „Journalistens integritet og publikum“, pp. 50-58 i Pressens Årbog 1976, København: Hans Reitzel.

Odd Raaum (2003): Dressur i pressen. Selvjustits i internasjonalt perspektiv. Oslo: Universitetsforlaget.

Kenneth Starck (2001): „What's Right/Wrong with Journalism Ethics Research?“, pp. 133-152 i Journalism Studies vol. 2, nr. 1.

Aage Trommer (1999): „Hvor fri var den danske presse under besættelsen?“, pp. 69-84 Hans Fredrik Dahl (red.): Sensur og selvsensur $i$ nordisk presse. Frederikstad, IJ.

Lennard Weibul (1990): „Pressetiska Bedömningar bland allmenheten“, pp. 105-121 i Pressens Årbog 199o, København: Hans Reitzel. 